\title{
ESTRUTURA CRUSTAL DO SETOR CENTRAL DA PROVÍNCIA TOCANTINS UTILIZANDO ONDAS P, $S$ E FASES REFLETIDAS COM DADOS DE REFRAÇÃO SÍSMICA PROFUNDA
}

\author{
Fábio André Perosi \\ Orientador: Dr. Jesus Antonio Berrocal Gomez (IAG-USP) \\ 136 p. - Tese (Doutorado) - Defesa 09.03.2006
}

\begin{abstract}
RESUMO. Esta pesquisa está baseada na execução de duas linhas de refração sísmica profunda de 300 km de extensão (L-1-Porangatu e L2Cavalcante) atravessando de oeste para leste o setor central da Província Tocantins, utilizando em cada linha 120 sismógrafos digitais e explosões com tempo controlado e cargas entre 500 e $1000 \mathrm{~kg}$ de explosivos a cada $50 \mathrm{~km}$; foram utilizados receptores GPS para o controle da hora e das coordenadas geográficas dos pontos de registro e de explosões. Esse tipo de experimento, com essas condições é pioneiro no Brasil. Os dados deste experimento, considerados de boa qualidade, permitiram, inicialmente, a elaboração de modelos 1D, para cada tiro, utilizando o programa TTInvers. Estes modelos foram relacionados sucessivamente para representar camadas com características semelhantes em um modelo preliminar para modelagem em 2D, que foi realizada com o programa MacRay. Os modelos 2D obtidos representam o resultado final da distribuição de velocidades sísmicas da crosta sob essas linhas. Estes resultados mostram a crosta sob o setor central da Província Tocantins com espessura variando entre 36 e $43 \mathrm{~km}$, cujos parâmetros estão correlacionados com as principais estruturas geológicas existentes na superfície. Os valores médios de Vp e da razão Vp/Ns na Província Tocantins variam em torno de 6,5 km/s e 1,74, respectivamente, com exceção da faixa de dobras e empurrões cujos valores são 6,3 km/s e 1,73. Sob o Cráton São Francisco esses valores são 6,8 km/s e 1,74. Existem indícios de ter ocorrido uma dupla subducção na Província Tocantins, na porção oriental, com 0 Cráton São Francisco subduzindo para oeste (em cerca de $760 \mathrm{Ma}$ ) e na porção ocidental, com 0 Cráton Amazônico subduzindo para leste (em cerca de $620 \mathrm{Ma}$ ). 0 modelo gravimétrico, obtido neste trabalho em função do modelo sísmico, se ajusta adequadamente com os dados gravimétricos observados, utilizando densidades teóricas ligeiramente modificadas, dentro dos limites permitidos pela função utilizada para calcular essas densidades com base nos valores de $V p$ deste trabalho. As densidades do manto adotadas para modelagem levaram em conta maior Vp (8,26 km/s), e Neoproterozóico, sob a Província Tocantins, mais densa $\left(3,34 \mathrm{~g} / \mathrm{cm}^{3}\right)$ e com menor Vp $(8,07 \mathrm{~km} / \mathrm{s})$.
\end{abstract}

ABSTRACT. This research is based on an execution of two lines of deep seismic refraction of $300 \mathrm{~km}$ of extension (L1-Porangatu and L2-Cavalcante), crossing over central sector of Tocantins Province from west to east by using, in each line, 120 digital seismographs and explosions with controlled time and explosive charges between 500 and 1,000 kg in each $50 \mathrm{~km}$; GPS receivers were employed in order to control the time and geographical coordinates from recording and shot points. This kind of experiment under these explained conditions is pioneer in Brazil. Initially experiment data, which have been considered of good quality, allowed the elaboration of $1 \mathrm{D}$ models, using TTInvers program. Successive models were related to represent layers with similar characteristics in a preliminary model aiming of modelling in 2D, accomplished with MacRay program. Obtained 2D models represent the final result of seismic velocity distribution from crust beneath $L 1$ and $L 2$ lines. Results show crust under central section of Tocantins Province with thickness varying from 36 to $43 \mathrm{~km}$, and whose parameters are correlated to main geological structures existents in surface. VP as well as VP/NS ratio mean values vary about $6.5 \mathrm{~km} / \mathrm{s}$ and 1.74 , respectively, with the exception of fold-and-thrust belt, whose values are $6.3 \mathrm{~km} / \mathrm{s}$ and 1.73. Those values reach $6.8 \mathrm{~km} / \mathrm{s}$ and 1.74 beneath São Francisco Craton. There are indicia of double subduction occurred in the eastern portion of Tocantins Province with São Francisco Craton subducting to west (in circa $760 \mathrm{Ma}$ ), as well as in the western portion, with Amazon Craton subducting to east (in circa $620 \mathrm{Ma)}$. The gravimetric model, obtained in this work in terms of seismic model, adequately adjusts with observed gravimetric data by using theoretical densities slightly modified, within limits allowed by the function employed to calculating the densities based on VP values achieved from this work. Adopted mantle densities to modelling took in consideration Paleoproterozoic age, beneath São Francisco Craton, less dense $\left(3.31 \mathrm{~g} / \mathrm{cm}^{3}\right)$, and with higher VP $(8.26 \mathrm{~km} / \mathrm{s})$, as well as Neoproterozoic one, beneath Tocantins Province, denser $\left(3.34 \mathrm{~g} / \mathrm{cm}^{3}\right)$, and with lower VP $(8.07 \mathrm{~km} / \mathrm{s})$. 